\title{
Effect of Conservation Agricultural and Nitrogen Management Practices on Productivity, Profitability, Nutrient-uptake and Response Functions of $\mathrm{N}$-fertilization in Wheat
}

\author{
R. L. Choudhary ${ }^{1 *}$ and U. K. Behera ${ }^{2}$ \\ ${ }^{1}$ Crop Production Unit, ICAR-Directorate of Rapeseed-Mustard Research, \\ Bharatpur, Rajasthan, India \\ ${ }^{2}$ College of Agriculture, Kyrdemkulai, CAU, Umiam, Meghalaya, India \\ *Corresponding author
}

\section{A B S T R A C T}

\begin{tabular}{l} 
Ke y w o r d s \\
Conservation \\
agriculture, \\
Economics, \\
Nitrogen response \\
functions, Nutrient \\
uptake, \\
Productivity, Wheat \\
\hline Article Info \\
\hline $\begin{array}{l}\text { Accepted: } \\
18 \text { March } 2020 \\
\text { Available Online: } \\
10 \text { April } 2020\end{array}$ \\
\hline
\end{tabular}

A field experiment was carried out at ICAR-Indian Agricultural Research Institute, New Delhi for two consecutive years to evaluate the effect of conservation agricultural and nitrogen management practices on productivity, profitability, nutrient-uptake and response functions of $\mathrm{N}$-fertilization in wheat in maize-wheat cropping system. There were six main-plot treatments of tillage and crop establishment techniques, i.e. conventional tillage-flat-bed (CT-F), CT-raised-bed (CT-B), zero tillage-flat-bed with crop-residue (ZT-F+R) and without crop-residue (ZT-F), ZT-raised-bed with crop residue $(\mathrm{ZT}-\mathrm{B}+\mathrm{R})$ and without crop-residue (ZT-B), and four sub-plot treatments of nitrogen (N; 0, 60, 120 and $180 \mathrm{~kg} \mathrm{~N} / \mathrm{ha}$ ). Results showed that leaf area index, relative growth rate, spike length, grains/spike, 1000-grains weight, biological yield, nutrient uptake and gross returns were recorded relatively high under ZT practices along with or without crop-residues over the CT practices, though difference among the treatments were non- significant. The biological yield, nutrient uptake (NPK) and gross returns were improved with CA practices (ZT-F+R/ZT-B+R) by 5.3-8.1, 4.8-10.1 and 7.3-10.9 \%, respectively over the CT practices. The B:C ratio was recorded the maximum under ZT practices (ZT-F/ZT-B) which was significantly higher by 18.3-24.0\% over the CT practices. Significantly higher values of most of the growth, yields, nutrient uptake and economic parameters were recorded at $120 \mathrm{~kg} \mathrm{~N} / \mathrm{ha}$. Nevertheless, ZT-F+R/ZT-B+R resulted the maximum response of wheat to $\mathrm{N}$-fertilization $(169-172 \mathrm{~kg} / \mathrm{ha}$ ) and also produced the maximum grain yield (4.81-4.86 t/ha) which signifying the importance of crop-residues and ZT technology in realizing the highest yield of wheat. Therefore, the study recommends that $\mathrm{CA}(\mathrm{ZT}-\mathrm{F}+\mathrm{R} / \mathrm{ZT}-\mathrm{B}+\mathrm{R})$ systems along with additional $50 \mathrm{~kg} \mathrm{~N} / \mathrm{ha}$ in addition to the presently recommended dose of $\mathrm{N}(120 \mathrm{~kg} / \mathrm{ha})$ should be promoted among the farmers of the Indo Gangetic Plains for improving productivity, profitability and long-term sustainability of the wheat in maize-wheat cropping system.

\section{Introduction}

Wheat (Triticum aestivum L.) being the important cereal crop of India, providing the food and nutritional security to the country by contributing around $35 \%$ in the national food grain production. The conventional wheat cultivation technologies primarily involving deep and intensively repeated tillage operations, over and indiscriminate use of water and fertilizer resources have significantly contributed in the occurrence of 
many ill-effects, though these have made the India self-sufficient in wheat production. The ill-effects of these technologies mainly include the soil health deterioration, ground water depletion and environmental pollution (Sharma et al., 2012; Jat et al., 2013).

Over-relaying on these technologies and over increasing input-costs have resulted the wheat cultivation non-profitable and unsustainable (Jat et al., 2019a; Jat et al., 2019b, Choudhary and Behera, 2020a). The conventional tillage (CT) practices are not only the major source of input energy consumption but also increase the costs of production, destroy the soil structure and lower the benefit: cost ratio (Choudhary and Behera, 2013; Singh et al., 2019; Choudhary and Behera, 2019, 2020b).

To obtain a good seed bed in CT system the repeated ploughings not only involve high expenditure but also consume time which many a times delay the sowing of the crops resulting in low yields in intensive cropping system where gap between the harvest of one crop and sowing of the next crop is very short.

Further, crop-residue burning is a common problem in CT-based production systems. Open-field burning of these crop-residues releases the soot-particles, green-houses gases in addition to loss of plant nutrients (Gathala et al., 2011; Jat et al., 2013; Choudhary et al., 2017).

In contrast to burning, retention of crop residue on soil surface as mulch helps in maintaining favorable hydrothermal regimes through modification of soil temperature and act as barrier against the loss of water. It improves the water and nutrient supply to crops and ultimately the crop productivity (Choudhary and Behera, 2014, 2019; Jat et al., 2019b).
The minimal soil movement by reduction in tillage intensity and retention of crop-residues on the soil surface along with crop rotations and diversification to economically benefit the farmers are the key principles of CA (Verhulst et al., 2011). The CA systems are being increasingly adopted in wheat-based cropping systems to reduce variable cultivation cost, enhance the resource-use efficiency and for restoration soil fertility (Jat et al., 2013; Jat et al., 2019c).

The zero-tillage (ZT) is cost effective, energy efficient and beneficial to environment as compared to CT practices of crop production (Jat et al., 2019c; Choudhary et al., 2020). Being the cereal, wheat is a heavy feeder of all nutrients in general, and nitrogen $(\mathrm{N})$ in particular. Therefore, provision for an adequate supply of $\mathrm{N}$ throughout the growing season is necessary for realizing the potential yields (Singh et al., 2009).

Further, it has also been observed that cereal crops exhibit reduced yields during the early phase of conversion of production technologies from CT to CA because of lesser $\mathrm{N}$ availability due to slower soil $\mathrm{N}$ mineralization, and greater immobilization, denitrification and $\mathrm{NH}_{3}$ volatilization losses in the latter systems (Patra et al., 2004). However, adoption of CA for long-run can enhance the supplying power of soil that leads to higher soil available $\mathrm{N}$ as compared to $\mathrm{CT}$ (Thuy et al., 2008).

All these complexities with $\mathrm{N}$ under $\mathrm{CA}$ indicate the need for more research to understand the response of $\mathrm{N}$ to wheat under CA systems so as optimal supply of $\mathrm{N}$ could be ensured. Accordingly, this study was conducted with the objective to investigate the effect of tillage, crop establishment techniques, and $\mathrm{N}$ management practices on agronomic productivity and profitability of wheat grown in sequence with maize. 


\section{Materials and Methods}

\section{Experimental location, soil and climatic conditions}

The study was conducted at the ICAR-Indian Agricultural Research Institute, New Delhi $\left(28.4^{\circ} \mathrm{N}, 77.1^{\circ} \mathrm{E}, 229 \mathrm{MASL}\right)$ during the winter seasons (November to April) of 200910 and 2010-11. The mean annual rainfall of the site is $672 \mathrm{~mm}$ out of which more than 80 $\%$ generally occurs during the monsoon season (July-September) with mean annual evaporation $850 \mathrm{~mm}$. At the start of the experiment, the soil was sandy loam in texture had $1.57 \mathrm{~g} / \mathrm{cm}^{3}$ bulk density, $17.48 \%$ (w/w) field capacity and $1.26 \mathrm{~cm} / \mathrm{hr}$ infiltration rate. The organic carbon, $\mathrm{KMnO}_{4}$ oxidizable $\mathrm{N}, 0.5 \mathrm{~N} \mathrm{NaHCO}_{3}$ extractable $\mathrm{P}$, $1.0 \mathrm{~N} \mathrm{NH} \mathrm{NHAc}_{4}$ exchangeable $\mathrm{K}, \mathrm{pH}$ and electrical conductivity of the soil were observed $0.37 \% 147.6 \mathrm{~kg} / \mathrm{ha}, 11.8 \mathrm{~kg} / \mathrm{ha}$, $235.1 \mathrm{~kg} / \mathrm{ha}, 7.5$ and $0.31 \mathrm{dS} / \mathrm{m}$, respectively.

\section{Treatment detail and crop cultural practices}

Field experiment was planned in split-plot design with three replications in a fixed layout. There were six main-plot treatment combinations of different tillage and crop establishment techniques: conventional tillage-flat (CT-F), zero tillage-flat (ZT-F), conventional tillage-bed (CT-B), zero tillagebed (ZT-B), ZT-flat with residue $(\mathrm{ZT}-\mathrm{F}+\mathrm{R})$ and ZT-bed with residue $(\mathrm{ZT}-\mathrm{B}+\mathrm{R})$, while four levels of nitrogen $(\mathrm{N})$ viz., 0, 60, 120 and $180 \mathrm{~kg} / \mathrm{ha}$ were superimposed in each mainplot. The CT consisted of two pass of a disc harrow, followed by two pass of cultivator with planking in the last pass. Raised beds (fresh bed) were made with a bed planter which made beds at distance of 26.57" from bed to bed with a bed height of 8 ". The ZT consisted of no-tillage with minimum soil disturbance and one pass of ZT seed drill for sowing of crop. In ZT-beds, one pass of bed planter was made for sowing of crop and reshaping of beds. The fresh and permanent raised beds were of 26.57" width having $14.76^{\prime \prime}$ top and 11.81" furrow, which was used for irrigation purposes. The wheat crop (var. PBW 550) was sown at a spacing of 18 $\mathrm{cm}$ from row to row with $100 \mathrm{~kg}$ seed/ha in flat planting, while three rows of wheat crop was established on top of the raised beds by keeping plant spacing of $5 \mathrm{~cm}$. The chopped residue of the previous maize crop was applied at $5.0 \mathrm{t} / \mathrm{ha}$ as per the treatments. Before sowing, weeds were controlled using tank mix paraquat + glyphosate (each $0.5 \mathrm{~kg}$ a.i./ha) in ZT practices. In standing wheat crop, tank mix solution of isoproturon (75 WP at $1 \mathrm{~kg}$ a.i./ha) and 2,4-D sodium salt (80 WP at $0.5 \mathrm{~kg}$ a.i./ha) was applied to control grassy as well as broad leaf weeds after 35 DAS. Full dose of P (26.2 kg/ha) and K (33.3 kg/ha) applied at the time of sowing in both the crops. Full dose of P (26.2 kg/ha) and K (33.3 $\mathrm{kg} / \mathrm{ha}$ ) applied at the time of sowing, while, $\mathrm{N}$ was applied in two equal splits (one at sowing and other after first irrigation) as per the treatments. The other standard and recommended practices of $\mathrm{CA}$ and $\mathrm{CT}$ were followed to harvest good crops.

\section{Monitoring of growth and yield parameters}

In flat sown wheat, $0.25 \mathrm{~m}^{2}$ areas was selected after leaving the first row from either side of the plot and the same area was selected from second bed of plot from the bed sown plots for the measurement of leaf area and dry matter accumulation. The crop leaves were stripped off from their base and total area of all the leaves was determined at 30, 60 and 90 DAS with the help of a Leaf Area Meter (Model LI-COR-3100). LAI was expressed as the ratio of leaf area to the land area occupied by the plant. The samples were sun dried first and then in an oven at $65^{\circ} \mathrm{C}$ till the constant weight arrived. 
The accumulated dry matter $\left(\mathrm{g} / \mathrm{m}^{2}\right)$ was used to calculate the relative growth rate $(\mathrm{RGR}$, $\mathrm{g} / \mathrm{g}$ /day) between 0-30, 30-60 and 60-90 DAS. The length of ten spikes were measured on a measuring scale and then their average value was expressed as length of spike in $\mathrm{cm}$. Ten ear-heads (spikes) from sampled plants were randomly selected, threshed and numbers of grains were counted. The average was worked out to obtain the number of grains/spike. A representative sample of grains was taken from the produce of each plot after drying and cleaning and weight of 1000-grains recorded and was expressed in grams. Total biomass of each net plot was harvested, weighed and expressed as biological yield in $\mathrm{t} / \mathrm{ha}$. Harvest index was computed by dividing the grain yield by the total biological yield and was expressed in percentage.

\section{Response functions of $\mathrm{N}$-fertilization and economics}

The economics of cultivation was worked out on the basis of prevailing market price of produce and cost of inputs. Gross returns were estimated by multiplying the grain yield and straw yields with their respective prices. While the cost: benefit ratio (B:C ratio) was calculated by dividing the net returns with total variable costs. Price of wheat produce was ₹ 11.00 and 11.50 per $\mathrm{kg}$ grain and ₹ 1.0 $\mathrm{kg} / \mathrm{straw}$ during 2009-10 and 2010-11, respectively. Response functions of $\mathrm{N}$ fertilization and their economics were calculated as described by Choudhary and Behera (2019).

\section{Nutrient uptake}

Plant samples collected at harvest were dried in hot air oven at $67^{\circ} \mathrm{C}$ for 24 hours. The oven dried plant sample and grain samples were ground in a Macro-Wiley Mill and used for the determination of total nitrogen $(\mathrm{N})$, phosphorus $(\mathrm{P})$ and potassium $(\mathrm{K})$ contents.
Concentrations of $\mathrm{N}, \mathrm{P}$ and $\mathrm{K}$ in grain and stover samples were determined by modified Kjeldahl method, vanadomolybdophosphoric acid yellow colour method (spectrophotometer) and flame photometer, respectively (Prasad et al., 2006). Accordingly, nutrient uptake by crop was calculated by multiplying nutrient concentration with respective grain and stover yields.

\section{Statistical analysis}

Analysis of variance was used to determine the effect of each treatment. When $F$ ratio was significant, a multiple mean comparison was performed using Fisher's LSD Test ( $p \leq 0.05$ probability level). The data were analyzed by two-way ANOVA technique using the PROCMIXED procedure of SAS package (ver. 9.3).

\section{Results and Discussion}

\section{Growth parameters}

The leaf area index (LAI) and relative growth rate (RGR) were found statistically similar under different tillage and crop establishment techniques at all the growth stages of wheat during both the years (Table 1 \& 2 ). However, the maximum values of these parameters at most of the growth stages were recorded under $\mathrm{ZT}-\mathrm{F}+\mathrm{R}$, while the minimum under CT-F. ZT practices have resulted marginally higher values of these parameters than corresponding CT practices. LAI was increased significantly with the advancement of the crop growth. It increased about 2.60 and 1.61 times at 60 and 90 DAS over the 30 and 60 DAS, respectively. However, RGR of wheat was decreased with advancement of crop growth and the maximum was recorded at 0-30 days interval, while the minimum between 60-90 days. Relatively higher values of growth parameters under ZT-F+R/ZT-B+R 
might be due to improved soil health and micro-environment created by continuous recycling of crop-residue and $\mathrm{ZT}$ practices. The growth parameters of wheat responded significantly to different levels of $\mathrm{N}$ in both the years. LAI was increased significantly up to $120 \mathrm{~kg} \mathrm{~N} / \mathrm{ha}$ at all the growth stages, except at 30 DAS where it responded significantly only up to $60 \mathrm{~kg} \mathrm{~N} / \mathrm{ha}$. RGR was increased significantly up to $120 \mathrm{~kg} \mathrm{~N} / \mathrm{ha}$ at $30 \mathrm{DAS}$, and only up to $60 \mathrm{~kg} \mathrm{~N} / \mathrm{ha}$ at rest of the growth stages. The overall improvement in growth of wheat with the addition of $\mathrm{N}$ could be ascribed to its pivotal role in several physiological and biochemical processes (Kibe et al., 2006).

\section{Yield attributes}

The effect of different tillage and crop establishment practices on the yield attributes viz. spike length, grains/spike and 1000-grain weight of wheat was non-significant during both the years (Table 3). However, most of these yield traits were recorded the maximum under ZT-F+R, while minimum under CT practices. Yadav et al., (2005) have reported that ZT led to improvement in growth and yield attributes, viz. plant height, effective tillers, grains/ear and 1000-grain weight due to better establishment of plants as a result of less weed competition under ZT. The yield

attributes were significantly influenced due to different levels of $\mathrm{N}$, except grains/spike during 2009-10 and 1000-grain weight during both the years. The spike length was responded significantly up to $120 \mathrm{~kg} \mathrm{~N} / \mathrm{ha}$, while other traits were improved significantly only up to $60 \mathrm{~kg} \mathrm{~N} / \mathrm{ha}$. Though, the maximum values of these parameters were recorded at $180 \mathrm{~kg} \mathrm{~N} / \mathrm{ha}$, except 1000-grain weight; which was recorded the maximum at $60 \mathrm{~kg}$ $\mathrm{N} / \mathrm{ha}$. Our findings are also in agreement with Kumar et al., (2007), they reported that yield attributing characters of wheat, spikes/m row and grains/spike enhanced significantly with each increase in $\mathrm{N}$ level up to $150 \mathrm{~kg} \mathrm{~N} / \mathrm{ha}$.

\section{Yield performance}

The biological yield and harvest index of wheat were also not influenced significantly due to different tillage and crop establishment technique during both the years (Table 4). However, the maximum biological yield was recorded under residue applied treatments (ZT-F+R/ ZT-B+R), which were recorded 5.3-8.1 \% higher over CT practices. Moreover, ZT without residue also registered the higher biological yield than the corresponding CT practices. Marginally higher biological yield was observed during 2010-11 than 2009-10 due to favourable weather conditions. Sayre et al., (2005) have reported that in the first 5 years of the experimentation, no significant differences in wheat yield were found between different tillage management systems.

However, comparatively higher yield of wheat under ZT-F+R/ZT-B+R might be due to moderated soil temperature, improved soil moisture and soil fertility with recycling of crop-residues. Ram et al., (2010) have reported higher yields under ZT with residue due to the cumulative effects of higher light interception more dry matter production, low soil and canopy temperature, more soil moisture, tillers, grains/ear and 1000-grain weight than no-residue application under ZT and CT practices.

Biological yield of wheat was significantly influenced due to different levels of $\mathrm{N}$. Biological yield was increased significantly with each successive levels of $\mathrm{N}$ from 0 to $120 \mathrm{Kg} / \mathrm{ha}$. However, highest values were obtained at $180 \mathrm{~kg} \mathrm{~N} / \mathrm{ha}$, which was significantly higher than 0 and $60 \mathrm{~kg} \mathrm{~N} / \mathrm{ha}$, but remained statistically similar with $120 \mathrm{~kg}$ $\mathrm{N} /$ ha. Being the cereal, wheat responded well 
up to $120 \mathrm{~kg} \mathrm{~N} /$ ha might also be due to that $\mathrm{N}$ supply boosts the crop growth and developmental processes because it involves in numbers of physiological and biochemical processes in plant system (Stitt and Krapp, 1999). Consequently, benefit derived by the crop in vegetative and reproductive developments due to optimal $\mathrm{N}$ supply might be the reason for higher yield of wheat at higher levels $\mathrm{N}$. The harvest index values were varied between 40.23 to $42.85 \%$, but it did not differ significantly. Similarly, harvest index was also not influenced significantly due to different levels of $\mathrm{N}$.

\section{Economics}

Gross returns were found statistically similar under different tillage and crop establishment techniques (Table 4). However, the maximum gross returns were recorded under residue applied treatments (ZT-F+R/ ZT-B+R), which were recorded 7.3-10.9\% higher over CT practices. The higher gross returns under ZT$\mathrm{F}+\mathrm{R} / \mathrm{ZT}-\mathrm{B}+\mathrm{R}$ were due to comparatively higher yields of wheat.

In contrast to other parameters, those did not influence significantly due to different tillage and crop establishment techniques, but the benefit: cost ratio (B:C ratio) was differed significantly (Table 4). The B:C ratio was recorded the maximum under $\mathrm{ZT}$ practices (ZT-F/ZT-B) which was significantly higher by $18.3-24.0 \%$ over the CT practices.

The higher $\mathrm{B}: \mathrm{C}$ ratio under $\mathrm{ZT}$ practices was due to comparatively higher yields and lesser cost incurred in crop establishment, weed control and manpower costs. This was in agreement with the findings of Zentner et al., (2002) and Choudhary and Behera (2020a). However, recycling of high value cropresidues under $\mathrm{ZT}$ practices reduced the $\mathrm{B}: \mathrm{C}$ ratio significantly over the $\mathrm{CT}$ practices. Gross returns were also increased with increase in $\mathrm{N}$ levels from 0 to $180 \mathrm{~kg} / \mathrm{ha}$, but it improved significantly up to $120 \mathrm{~kg} \mathrm{~N} / \mathrm{ha}$. While $\mathrm{B}: \mathrm{C}$ ratio was increased significantly only up to $60 \mathrm{~kg} \mathrm{~N} / \mathrm{ha}$.

\section{Nutrient uptake}

The total nutrient uptake (N, P and $\mathrm{K}$ ) in grain and straw of wheat crop were not influenced significantly due to different tillage and crop establishment techniques during both the years (Table 5). However, the maximum uptake of $\mathrm{N}, \mathrm{P}$ and $\mathrm{K}$ was recorded under residue applied $\mathrm{ZT}$ treatments $(\mathrm{ZT}-\mathrm{F}+\mathrm{R} / \mathrm{ZT}$ $\mathrm{B}+\mathrm{R})$, which were found 5.0-9.9, 8.1-10.1 and 4.8-5.5\% higher over the CT practices, respectively.

The recycling of maize-residues might have contributed in nutrient supply in soil layers and ultimately enhances nutrient availability for wheat which might be the reason for higher uptake of nutrients under CA practices (Choudhary and Behera, 2019).

Unlike, the effect of different tillage and crop establishment techniques on nutrients uptake, various levels of $\mathrm{N}$ significantly influenced the nutrients uptake of wheat. The uptake of $\mathrm{N}, \mathrm{P}$ and $\mathrm{K}$ was increased significantly with each increased levels of $\mathrm{N}$ up to $120 \mathrm{~kg}$ N/ha.

However, the maximum values of $\mathrm{N}, \mathrm{P}$ and $\mathrm{K}$ uptake were recorded at $180 \mathrm{~kg} \mathrm{~N} / \mathrm{ha}$, which remained significantly higher than 0 and 60 $\mathrm{kg} \mathrm{N} / \mathrm{ha}$, but statistically on par with $120 \mathrm{~kg}$ $\mathrm{N} / \mathrm{ha}$. Relatively higher concentration of N, P and $\mathrm{K}$ in grain and straw and higher biomass yields of wheat might be the reason for higher uptake of these nutrients at higher levels of $\mathrm{N}$.

\section{Response functions of $\mathbf{N}$-fertilization}

Wheat responded differentially to $\mathrm{N}$ levels under different tillage and crop-establishment techniques. The response of wheat to $\mathrm{N}$ was 
quadratic (Fig. 1). Almost similar response of $\mathrm{N}$ was observed in different $\mathrm{CT}$ and $\mathrm{ZT}$ without crop-residue practices. However, greater response of $\mathrm{N}$ was observed under crop-residue applied ZT treatments. Further, crop-residue applied treatments responded differentially in terms of yield enhancement under varying levels of $\mathrm{N}$, indicating that the beneficial effect of crop-residue recycling was more discernible when $\mathrm{N}$ levels were increased from zero to highest.

Beneficial effect of crop-residues under ZT$\mathrm{F}+\mathrm{R} / \mathrm{ZT}-\mathrm{B}+\mathrm{R}$ was increased with each successive higher level of $\mathrm{N}$, but at slower pace between 0 and $120 \mathrm{~kg} \mathrm{~N} / \mathrm{ha}$ and highest between 120 and $180 \mathrm{~kg} \mathrm{~N} / \mathrm{ha}$. The response functions of $\mathrm{N}$ fertilization were worked out by quadratic equations between the grain yields and $\mathrm{N}$ levels (Table 6).

The $\mathrm{N}_{\text {opt }}$ for wheat was observed higher than the recommended dose of $\mathrm{N}(120 \mathrm{~kg} \mathrm{~N} / \mathrm{ha})$ under all the treatments, indicating that little higher doses of $\mathrm{N}$ are needed to achieve higher wheat yields. The $\mathrm{N}_{\text {opt }}$ for wheat was recorded least under CT-F, followed by other $\mathrm{CT}$ and ZT without residue treatments, indicating that yield could not be increased further under these practices even with the application of higher dose of $\mathrm{N}$.

The maximum grain yield of wheat was estimated under ZT-F+R and ZT-B+R treatments were 172.1 and $168.9 \mathrm{~kg} \mathrm{~N} / \mathrm{ha}$ $\left(\mathrm{N}_{\mathrm{opt}}\right)$, respectively, indicating that wheat require around additional $50 \mathrm{~kg} \mathrm{~N} / \mathrm{ha}$ to realize its potential yields under CA systems during the initial years.

Thus, maize residue recycled to wheat under ZT practices had increased the dose of $\mathrm{N}_{\mathrm{opt}}$ for wheat which led to lower response in $\mathrm{kg}$ grain/kg N than CT and ZT without residueapplied treatments, though it produced the maximum grain yield of wheat.

Table.1 Effect of tillage and crop establishment techniques, and $\mathrm{N}$ levels on leaf area index of wheat

\begin{tabular}{|c|c|c|c|c|c|c|}
\hline \multirow[t]{2}{*}{ Treatment } & \multicolumn{2}{|c|}{30 DAS } & \multicolumn{2}{|c|}{60 DAS } & \multicolumn{2}{|c|}{90 DAS } \\
\hline & 2009-10 & 2010-11 & 2009-10 & 2010-11 & 2009-10 & 2010-11 \\
\hline \multicolumn{7}{|c|}{ Tillage and crop establishment } \\
\hline CT-F & 0.69 & 0.73 & 1.95 & 2.01 & 3.20 & 3.27 \\
\hline CT-B & 0.69 & 0.86 & 1.96 & 2.12 & 3.32 & 3.41 \\
\hline ZT-F & 0.70 & 0.73 & 2.17 & 2.22 & 3.46 & 3.51 \\
\hline ZT-B & 0.70 & 0.73 & 2.05 & 2.13 & 3.39 & 3.43 \\
\hline ZT-F+R & 0.70 & 0.78 & 2.20 & 2.29 & 3.58 & 3.62 \\
\hline ZT-B+R & 0.70 & 0.84 & 2.07 & 2.19 & 3.37 & 3.52 \\
\hline SEm \pm & 0.013 & 0.033 & 0.065 & 0.069 & 0.100 & 0.101 \\
\hline $\operatorname{LSD}(p \leq 0.05)$ & NS & NS & NS & NS & NS & NS \\
\hline \multicolumn{7}{|c|}{ Nitrogen levels (kg/ha) } \\
\hline $\mathbf{0}$ & 0.63 & 0.70 & 1.61 & 1.71 & 2.47 & 2.54 \\
\hline 60 & 0.71 & 0.79 & 2.15 & 2.24 & 3.36 & 3.44 \\
\hline 120 & 0.72 & 0.82 & 2.24 & 2.34 & 3.84 & 3.89 \\
\hline 180 & 0.72 & 0.81 & 2.26 & 2.35 & 3.87 & 3.97 \\
\hline SEm \pm & 0.009 & 0.018 & 0.031 & 0.029 & 0.036 & 0.043 \\
\hline $\operatorname{LSD}(p \leq 0.05)$ & 0.026 & 0.051 & 0.089 & 0.084 & 0.103 & 0.122 \\
\hline
\end{tabular}


Table.2 Effect of tillage and crop establishment techniques, and $\mathrm{N}$ levels on relative growth rate $(\mathrm{g} / \mathrm{g} /$ day $)$ of wheat

\begin{tabular}{|c|c|c|c|c|c|c|}
\hline \multirow[t]{2}{*}{ Treatment } & \multicolumn{2}{|c|}{ 0-30 DAS } & \multicolumn{2}{|c|}{ 30-60 DAS } & \multicolumn{2}{|c|}{ 60-90 DAS } \\
\hline & 2009-10 & 2010-11 & 2009-10 & 2010-11 & 2009-10 & 2010-11 \\
\hline \multicolumn{7}{|l|}{$\begin{array}{l}\text { Tillage and crop } \\
\text { establishment }\end{array}$} \\
\hline CT-F & 0.112 & 0.123 & 0.026 & 0.046 & 0.020 & 0.052 \\
\hline CT-B & 0.113 & 0.124 & 0.029 & 0.043 & 0.019 & 0.050 \\
\hline ZT-F & 0.112 & 0.127 & 0.026 & 0.041 & 0.020 & 0.051 \\
\hline ZT-B & 0.113 & 0.123 & 0.028 & 0.044 & 0.019 & 0.051 \\
\hline ZT-F+R & 0.112 & 0.129 & 0.026 & 0.039 & 0.019 & 0.051 \\
\hline ZT-B+R & 0.114 & 0.128 & 0.028 & 0.038 & 0.019 & 0.050 \\
\hline SEm \pm & 0.001 & 0.002 & 0.001 & 0.002 & 0.001 & 0.001 \\
\hline $\operatorname{LSD}(p \leq 0.05)$ & NS & NS & NS & NS & NS & NS \\
\hline \multicolumn{7}{|c|}{ Nitrogen levels $(\mathrm{kg} / \mathrm{ha})$} \\
\hline $\mathbf{0}$ & 0.104 & 0.118 & 0.029 & 0.046 & 0.017 & 0.047 \\
\hline 60 & 0.113 & 0.126 & 0.026 & 0.041 & 0.019 & 0.050 \\
\hline 120 & 0.116 & 0.129 & 0.027 & 0.040 & 0.020 & 0.052 \\
\hline 180 & 0.117 & 0.130 & 0.026 & 0.039 & 0.021 & 0.053 \\
\hline SEm \pm & 0.0004 & 0.001 & 0.001 & 0.001 & 0.001 & 0.001 \\
\hline LSD $(p \leq 0.05)$ & 0.001 & 0.003 & 0.002 & 0.003 & NS & 0.002 \\
\hline
\end{tabular}

Table.3 Effect of tillage and crop establishment techniques, and $\mathrm{N}$ levels on yield attributes of wheat

\begin{tabular}{|c|c|c|c|c|c|c|}
\hline \multirow[t]{2}{*}{ Treatment } & \multicolumn{2}{|c|}{ Spike length (cm) } & \multicolumn{2}{|c|}{ Grains/spike } & \multicolumn{2}{|c|}{ 1000-grain weight (g) } \\
\hline & 2009-10 & 2010-11 & 2009-10 & 2010-11 & 2009-10 & 2010-11 \\
\hline \multicolumn{7}{|c|}{ Tillage and crop establishment } \\
\hline CT-F & 10.13 & 10.64 & 53.31 & 54.93 & 40.66 & 39.11 \\
\hline CT-B & 10.10 & 10.07 & 54.30 & 52.73 & 39.47 & 41.68 \\
\hline ZT-F & 10.14 & 10.77 & 58.00 & 57.53 & 39.84 & 42.66 \\
\hline ZT-B & 10.17 & 10.76 & 57.48 & 57.43 & 41.16 & 40.59 \\
\hline ZT-F+R & 10.18 & 10.69 & 56.03 & 60.33 & 41.45 & 42.84 \\
\hline ZT-B+R & 10.14 & 10.56 & 58.70 & 59.47 & 41.16 & 39.84 \\
\hline SEm \pm & 0.163 & 0.208 & 2.433 & 2.846 & 0.725 & 1.403 \\
\hline $\operatorname{LSD}(p \leq 0.05)$ & NS & NS & NS & NS & NS & NS \\
\hline \multicolumn{7}{|c|}{ Nitrogen levels $(\mathrm{kg} / \mathrm{ha})$} \\
\hline 0 & 8.84 & 8.90 & 52.96 & 49.50 & 40.90 & 38.96 \\
\hline 60 & 10.44 & 10.12 & 55.77 & 56.30 & 41.27 & 42.46 \\
\hline 120 & 10.62 & 11.54 & 57.63 & 60.41 & 40.34 & 42.13 \\
\hline 180 & 10.66 & 11.75 & 58.85 & 62.05 & 39.98 & 40.93 \\
\hline SEm \pm & 0.129 & 0.195 & 1.549 & 2.355 & 0.631 & 1.252 \\
\hline $\operatorname{LSD}(p \leq 0.05)$ & 0.369 & 0.559 & NS & 6.754 & NS & NS \\
\hline
\end{tabular}


Tanle.4 Effect of tillage and crop establishment techniques, and $\mathrm{N}$ levels on yield performance and economics of wheat

\begin{tabular}{|c|c|c|c|c|c|c|c|c|}
\hline \multirow[t]{2}{*}{ Treatment } & \multicolumn{2}{|c|}{$\begin{array}{c}\text { Biological yield } \\
\text { (t/ha) }\end{array}$} & \multicolumn{2}{|c|}{$\begin{array}{c}\text { Harvest index } \\
(\%)\end{array}$} & \multicolumn{2}{|c|}{$\begin{array}{l}\text { Gross returns } \\
\left(\times 10^{3} ₹ / h a\right)\end{array}$} & \multicolumn{2}{|c|}{ B:C ratio } \\
\hline & $\begin{array}{c}2009- \\
10\end{array}$ & $\begin{array}{c}2010- \\
11\end{array}$ & $\begin{array}{c}2009- \\
10\end{array}$ & $\begin{array}{c}2010- \\
11\end{array}$ & $\begin{array}{c}2009- \\
10\end{array}$ & $\begin{array}{c}2010- \\
11\end{array}$ & $\begin{array}{c}2009- \\
10\end{array}$ & $\begin{array}{c}2010- \\
11\end{array}$ \\
\hline \multicolumn{9}{|c|}{ Tillage and crop establishment } \\
\hline CT-F & 9.07 & 9.43 & 41.31 & 40.25 & 49.55 & 51.97 & 1.68 & 2.03 \\
\hline CT-B & 8.94 & 9.66 & 41.24 & 40.23 & 48.46 & 53.24 & 1.60 & 2.06 \\
\hline ZT-F & 9.26 & 9.82 & 42.51 & 40.86 & 51.37 & 54.83 & 2.03 & 2.51 \\
\hline ZT-B & 8.96 & 9.59 & 41.70 & 40.74 & 48.83 & 53.07 & 1.94 & 2.45 \\
\hline ZT-F+R & 9.86 & 10.14 & 42.85 & 41.82 & 55.05 & 57.56 & 1.47 & 1.75 \\
\hline ZT-B+R & 9.72 & 9.86 & 41.50 & 41.77 & 53.06 & 56.04 & 1.42 & 1.71 \\
\hline SEm \pm & 0.369 & 0.359 & 1.671 & 2.071 & 1.70 & 1.31 & 0.10 & 0.077 \\
\hline LSD $(p \leq 0.05)$ & NS & NS & NS & NS & NS & NS & 0.31 & 0.241 \\
\hline \multicolumn{9}{|c|}{ Nitrogen levels $(\mathrm{kg} / \mathrm{ha})$} \\
\hline $\mathbf{0}$ & 6.85 & 6.93 & 40.59 & 41.82 & 36.67 & 39.36 & 1.13 & 1.48 \\
\hline 60 & 9.35 & 9.90 & 42.26 & 41.22 & 51.57 & 55.65 & 1.79 & 2.26 \\
\hline 120 & 10.32 & 10.93 & 42.30 & 40.31 & 56.98 & 60.47 & 1.93 & 2.34 \\
\hline 180 & 10.70 & 11.24 & 42.27 & 40.44 & 58.99 & 62.34 & 1.90 & 2.26 \\
\hline SEm \pm & 0.156 & 0.181 & 1.270 & 1.242 & 0.85 & 1.03 & 0.05 & 0.063 \\
\hline LSD $(p \leq 0.05)$ & 0.448 & 0.519 & NS & NS & 2.44 & 2.96 & 0.14 & 0.180 \\
\hline
\end{tabular}

Table.5 Effect of tillage and crop establishment techniques, and $\mathrm{N}$ levels on nutrient uptake $(\mathrm{kg} / \mathrm{ha})$ of wheat

\begin{tabular}{|c|c|c|c|c|c|c|}
\hline \multirow[t]{2}{*}{ Treatment } & \multicolumn{2}{|c|}{ Total nitrogen } & \multicolumn{2}{|c|}{ Total phosphorous } & \multicolumn{2}{|c|}{ Total potassium } \\
\hline & 2009-10 & 2010-11 & 2009-10 & 2010-11 & 2009-10 & 2010-11 \\
\hline \multicolumn{7}{|c|}{ Tillage and crop establishment } \\
\hline CT-F & 83.51 & 83.53 & 9.98 & 10.16 & 101.75 & 108.2 \\
\hline CT-B & 85.35 & 88.36 & 9.41 & 10.24 & 100.20 & 108.5 \\
\hline ZT-F & 82.92 & 86.05 & 10.12 & 10.63 & 99.95 & 108.7 \\
\hline ZT-B & 83.32 & 86.93 & 9.52 & 10.13 & 99.74 & 108.2 \\
\hline ZT-F+R & 91.10 & 92.55 & 10.98 & 11.20 & 108.74 & 112.7 \\
\hline ZT-B+R & 89.82 & 92.52 & 10.42 & 10.82 & 108.94 & 109.8 \\
\hline SEm \pm & 3.709 & 2.146 & 0.41 & 0.370 & 3.412 & 3.890 \\
\hline $\operatorname{LSD}(p \leq 0.05)$ & NS & NS & NS & NS & NS & NS \\
\hline \multicolumn{7}{|c|}{ Nitrogen levels $(\mathrm{kg} / \mathrm{ha})$} \\
\hline $\mathbf{0}$ & 55.01 & 56.73 & 7.09 & 7.458 & 75.14 & 74.41 \\
\hline 60 & 85.54 & 89.91 & 10.18 & 10.74 & 103.48 & 110.2 \\
\hline 120 & 99.84 & 102.43 & 11.33 & 11.79 & 115.50 & 124.3 \\
\hline 180 & 103.62 & 104.23 & 11.70 & 12.13 & 118.75 & 128.6 \\
\hline SEm \pm & 1.746 & 1.749 & 0.19 & 0.233 & 2.460 & 3.180 \\
\hline $\operatorname{LSD}(p \leq 0.05)$ & 5.008 & 5.018 & 0.55 & 0.667 & 7.055 & 9.121 \\
\hline
\end{tabular}


Table.6 Effect of tillage and crop-establishment techniques on response function of nitrogen fertilization of wheat during 2010-11

\begin{tabular}{|l|c|c|c|}
\hline Treatment & $\begin{array}{c}\text { Economic } \\
\text { optimum dose of } \\
\mathbf{N}(\mathbf{k g} / \mathbf{h a})\end{array}$ & $\begin{array}{c}\text { Grain yield at economic } \\
\text { optimum dose of N (kg } \\
\text { grain/ha) }\end{array}$ & $\begin{array}{c}\text { Response at economic } \\
\text { optimum dose of N } \mathbf{( k g} \\
\text { grain/kg N) }\end{array}$ \\
\hline CT-F & 128.3 & 4395 & 13.4 \\
\hline CT-B & 135.3 & 4485 & 12.7 \\
\hline ZT-F & 133.1 & 4642 & 13.4 \\
\hline ZT-B & 132.9 & 4372 & 10.7 \\
\hline ZT-F+R & 172.1 & 4862 & 10.1 \\
\hline ZT-B+R & 168.9 & 4805 & 9.5 \\
\hline
\end{tabular}

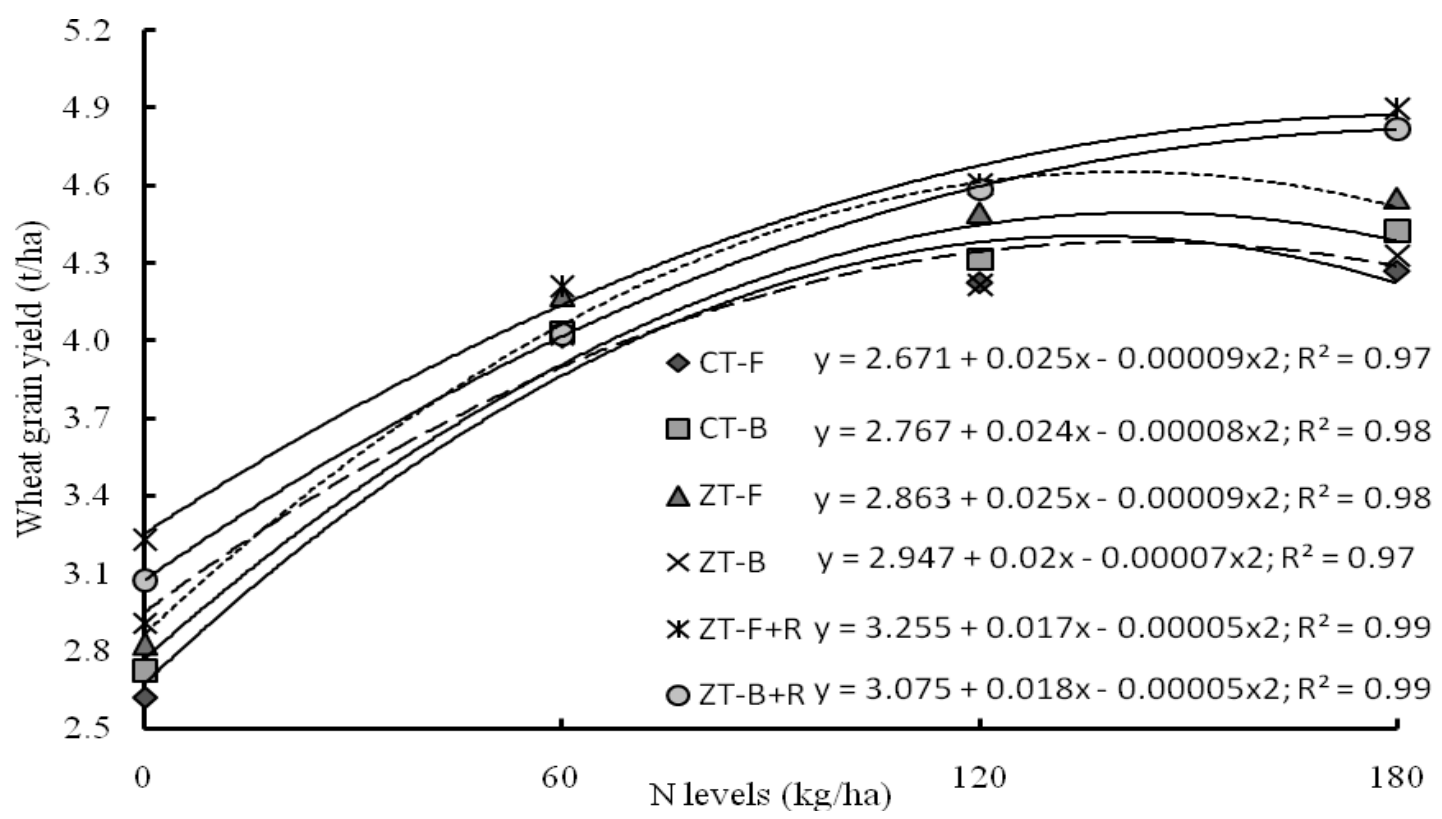

Fig.1 Response of wheat to varying levels of $\mathrm{N}$ as influenced by different tillage and cropestablishment techniques

However, Sharma and Behera (2009) reported that $\mathrm{N}$ economy in wheat was $21 \mathrm{~kg} \mathrm{~N} / \mathrm{ha}$ owing to residue incorporation of intercropped greengram, cowpea and groundnut; and $49-56 \mathrm{~kg} \mathrm{~N} / \mathrm{ha}$ of sole cropped greengram and groundnut. Similarly, Choudhary and Behera (2019) have also reported an N economy of $20-25 \mathrm{~kg} / \mathrm{ha}$ in maize due to wheat residue recycling under the CA systems.

Thus, it can be concluded that the growth, yield attributes, nutrient uptake and yields of wheat were observed relatively higher under ZT practices along with or without crop residues over the CT practices. However, ZT technology was found most profitable with highest $\mathrm{B}: \mathrm{C}$ ratio. Recycling of crop-residues under $\mathrm{ZT}$ practices resulted the maximum response of wheat to $\mathrm{N}$ fertilization and also yielded the maximum which signifying the importance of crop-residues and $\mathrm{ZT}$ technology in realizing the highest potential yield of wheat. Therefore, the study recommends that CA (ZT-F+R/ZT-B+R) system along with additional $50 \mathrm{~kg} \mathrm{~N} / \mathrm{ha}$ in 
addition to the presently recommended dose of $\mathrm{N}(120 \mathrm{~kg} / \mathrm{ha})$ should be promoted among the farmers of the Indo Gangetic Plains for improving productivity, profitability and long-term sustainability of wheat in maizewheat cropping system.

\section{Acknowledgement}

The authors greatly acknowledge the ICARIndian Agricultural Research Institute (IARI), New Delhi for providing the field and laboratory facilities and financial help for smooth conduct of the study.

\section{References}

Choudhary, R.L. and Behera, U.K. 2013. Effect of sequential tillage practices and $\mathrm{N}$ levels on energy relations and useefficiencies of irrigation water and $\mathrm{N}$ in maize (Zea mays)-wheat (Triticum aestivum) cropping system. Indian $\mathrm{J}$. Agron. 58(1): 27-34.

Choudhary, R.L. and Behera, U.K. 2014. Effect of sequential tillage practices and $\mathrm{N}$ levels on soil health and root parameters in maize (Zea mays)-wheat (Tritium aestivum) cropping system. J. Soil Water Cons. 13(1): 73-82.

Choudhary, R.L., Wakchaure, G.C., Minhas, P.S. and Singh, A.K. 2017. Response of ratoon sugarcane to stubble shaving, off-barring, root pruning and band placement of basal fertilisers with a multi-purpose drill machine. Sugar Tech. 19(1): 33-40.

Choudhary, R.L. and Behera, U.K. 2019. Conservation agricultural and nitrogen management practices in maize-wheat cropping system: Effect on productivity, nutrient uptake and profitability of maize. Indian J. Soil Cons. 47(3): 286293.

Choudhary, R.L. and Behera, U.K. 2020a. Conservation agriculture and nitrogen management in maize-wheat cropping system: effect on growth, productivity and economics of wheat. Int. J. Chem. Stud. (Accepted).

Choudhary, R..L, Behera, U.K. 2020 b. Resource-use Efficiency of Wheat: Effect of Conservation Agriculture and Nitrogen Management Practices in Maize (Zea mays)-wheat (Triticum aestivum) Cropping System. Int. J. Curr. Microbiol. App. Sci. 9(04). (Accepted).

Choudhary, R.L., Behera, U.K., Singh, H.V., Meena, M.D., Dotaniya, M.L., Jat, R.S. 2020. Energetics and nitrogen-use efficiency of kharif maize in conservation agriculture-based maize (Zea mays)-wheat (Triticum aestivum) sequence. Int. J. Chem. Stud. 2020: 8(2):1252-1258.

Gathala, M.K., Ladha, J.K., Saharawat, Y.S., Kumar, V., Kumar, V., Sharma, P.K. 2011. Eff ect of tillage and crop establishment methods on physical properties of a medium textured soil under a seven-year rice-wheat rotation. . Soil Sci. Soc. Am. J. 75: 1851-1862.

Jat, H.S., Datta, A., Choudhary, M., Yadav, A.K., Choudhary, V., Sharma, P.C., Gathala, M.K. et al., 2019a. Effects of tillage, crop establishment and diversification on soil organic carbon, aggregation, aggregate associated carbon and productivity in cereal systems of semi-arid Northwest India. Soil Till. Res. 190: 128-138.

Jat, M.L., Gathala, M.K., Saharawat, Y.S., Tetarwal, J.P., Gupta, R. and Singh, Y. 2013. Double no-till and permanent raised beds in maize-wheat rotation of north-western Indo-Gangetic plains of India: Effects on crop yields, water productivity, profitability and soil physical properties. Field Crop Res. 149: 291-99.

Jat, R.K., Singh, R.G., Kumar, M., Jat, M.L., Parihar, C.M., Bijarniya, D., Sutaliya, 
J.M. et al., 2019b. Ten years of conservation agriculture in a rice-maize rotation of Eastern Gangetic Plains of India: Yield trends, water productivity and economic profitability. Field Crop Res. 232:1-10.

Jat, S.L., Parihar, C.M., Singh, A.K., Kumar, B., Choudhary, M., Nayak, H.S., et al., 2019c. Energy auditing and carbon footprint under long-term conservation agriculture-based intensive maize systems with diverse inorganic nitrogen management options. Sci. Total Environ. 664: 659-668.

Kibe, A.M., Singh, S. and Kalra N. 2006. Water-nitrogen relationship for wheat growth and productivity in late sown conditions. Agric. Water Manag. 84: 21-228.

Kumar, R., Aggarwal, S.K. and Nanwal, R.K. 2007. Effect of planting systems, seed rates and nitrogen levels on bread wheat (Triticum aestivum). Indian J. Agric. Sci. 77(10): 669-671.

Patra, A.K., Chhonkar, P.K. and Khan, M.A. 2004. Nitrogen loss and wheat (Triticum aestivum) yields in response to zerotillage and sowing time in a semi-arid tropical environment. J. Agron. Crop Sci. 190: 324-31.

Prasad, R., Shivay, Y.S., Kumar, D. and Sharma, S.N. 2006. Learning by doing exercise in soil fertility (A practical manual for soil fertility). Division of Agronomy, Indian Agricultural Research Institute, New Delhi. p. 68.

Ram, H., Kler, D.S., Singh, Y. and Kumar, K. 2010. Productivity of maize (Zea mays)-wheat (Triticum aestivum) system under different tillage and crop establishment practice. Indian J. Agron. 55(3): 185-190.

Sayre, K.D., Limon-Ortega, A. and Govaerts, B. 2005. Experiences with permanent bed planting systems CIMMYT, Mexico. In: proceedings of Workshop on Evaluation and Performance of Permanent Raised Bed Cropping Systems in Asia, Australia and Mexico 1-3 March, Griffith, Australia, pp. 1225.

Sharma, A.R., Jat, M.L., Saharawat, Y.S., Singh, V.P. and Singh, R. 2012. Conservation agriculture for improving productivity and resource-use efficiency: prospects and research needs in Indian context. Indian J. Agron. 57: 131-140.

Sharma, A.R. and Behera, U.K. 2009. Recycling of legume residue for nitrogen economy and higher productivity in maize (Zea mays)-wheat (Triticum aestivum) cropping system. Nutr. Cycl. Agroecosys. 83:197-210.

Singh, R., Rai, A.K., Kumari, R., Sharma, D.K., Kumar, S., Joshi, P.K., Chaudhari, S.K., Sharma, P.C., Singh, A. and Babli 2019. Long term effect of crop residue and tillage on carbon sequestration, soil aggregation and crop productivity in rice (Oryza sativa)wheat (Triticum aestivum) cropping system under partially reclaimed sodic soils. Indian J. Agron. 64(1): 11-17.

Singh, Y., Gupta, R.K., Singh, G., Singh, J., Sindhu, H.S. and Singh, B. 2009. Nitrogen and residue management effects on agronomic productivity and nitrogen use efficiency in rice-wheat system in Indian Punjab. Nutr. Cycl. Agroecosys. 84: 141-154.

Stitt, M. and Krapp, A. 1999. The interaction between elevated carbon dioxide and nitrogen nutrition: the physiological and molecular background. Plant Cell Environ. 22: 583-621.

Verhulst, N., Kienlem, F., Sayre, K., Deckers, J., Raes, D., Limon-Ortega, A., et al., 2011. Soil quality as affected by tillageresidue management in a wheat-maize irrigated bed-planting system. Plant Soil. 340: 453-66. 
Yadav, D.S., Shukla, R.P., Sushant and Kumar, B. 2005. Effect of zero tillage and nitrogen level on wheat (Triticum aestivum) after rice (Oryza sativa). Indian J.Agron. 50(1): 52-53.

Thuy, N.H., Yuhuna, S., Singh, S., Wang, K., Cai, Z., Singh, Y. and Buresh, R.J. 2008. Nitrogen supply in rice -based cropping systems as affected by crop residue management. Soil Sci. Soc. Am. J. 72: 514-523.

Zentner, R.P., Lafond, G.P., Derksen, D.A. and Campbell, C.A. 2002. Tillage method and crop diversification: Effect on economic returns and riskiness of cropping systems in a thin black chernozem of the Canadian prairies. Soil Till. Res. 67: 9-21.

\section{How to cite this article:}

Choudhary, R. L. and Behera, U. K. 2020. Effect of Conservation Agricultural and Nitrogen Management Practices on Productivity, Profitability, Nutrient-uptake and Response Functions of N-fertilization in Wheat. Int.J.Curr.Microbiol.App.Sci. 9(04): 2131-2143. doi: https://doi.org/10.20546/ijcmas.2020.904.256 